\title{
PENGARUH PELATIHAN PENYUSUNAN SOAL MENGGUNAKAN MOODLE TERHADAP KINERJA GURU DALAM MENYUSUN SOAL TEST DI SMAN 100 JAKARTA
}

\author{
Ruslan Hadi $^{1}$, Yuliatri Sastrawijaya ${ }^{2}$, Vina Oktaviani ${ }^{3}$ \\ ${ }^{1}$ Mahasiswa Prodi PendidikanTeknik Informatika dan Komputer, ${ }^{2}$ Teknik Elektro, FT - UNJ, \\ ${ }^{3}$ Dosen Prodi Pendidikan Teknik Informatika dan Komputer, Teknik Elektro, FT - UNJ \\ ${ }^{1}$-ruslanhadi100@gmail.com, ${ }^{2}$ yuliatri@unj.ac.id, ${ }^{3}$-vinaoktaviani@unj.ac.id
}

\begin{abstract}
Abstrak
Penelitian ini bertujuan untuk mengetahui pengaruh pelatihan penyusunan soal menggunakan Moodle terhadap kinerja guru dalam menyusun butir soal test di SMA Negeri 100 Jakarta. Penelitian ini menggunakqn metode survey (field study) dengan menggunakan pendekatan korelasional. Sampel penelitian adalah seluruh anggota populasi berjumlah 37 orang. Metode pengumpulan data menggunakan angket dan dokumentasi. Berdasarkan hasil pengujian data yang telah dilakukan ditemukan bahwa pengujian hipotesis memperoleh keputusan bahwa terdapat hubungan positif dan signifikan antara Pelatihan Penyusunan Soal dengan Kinerja Guru dalam Menyusun Soal Test di SMAN 100 Jakarta. Dari perhitungan uji normalitas data, diperoleh hasil untuk data instrumen kinerja guru dengan $L_{\text {hitung }}=0,138$ dan data instrumen pelatihan penyusnan soal $L_{h i t u n g}=$ 0,141 dengan $L_{t a b e l}=0,146$. Artinya, data dari kedua instrumen berdistribusi normal. Sedangkan untuk hasil pengujian hipotesis memperoleh nilai 0,735. Artinya, korelasi antara variabel $x$ dan variabel y kuat. Data ini menunjukkan bahwa terdapat hubungan yang positif antara pelatihan penyusunan soal menggunakan moodle dengan kinerja guru dalam menyusun soal tes di SMAN 100 Jakarta
\end{abstract}

Kata kunci : Pelatihan, Kinerja Guru, Penyusunan Soal

\section{Pendahuluan}

\subsection{Latar Belakang}

Menjadi seorang guru harus memiliki keahlian, keterampilan dan kemampuan menguasai materi, selain itu guru juga dapat menjadi contoh teladan bagi siswa. Untuk itu guru harus selalu meningkatkan kinerjanya di sekolah. Kinerja guru dapat diihat dan diukur berdasarkan kriteria kompetensi yang dimiliki guru seperti:1) kompetensi pedagogik, 2) kompetensi kepribadian, 3) kompetensi sosial, 4) kompetensi profesional. Jika seorang guru menjalankan prinsip-prinsip dari profesionalisme dalam menjalankan tugas dan fungsinya akan menghasilkan kinerja yang baik. Keberhasilan guru dalam proses pembelajaran sangat ditentukan oleh kompetensi guru sebagai pendidik. Kompetensi guru merupakan kemampuan seorang guru dalam melaksanakan tugas pembelajaran dan bertanggung jawab atas siswa. Kompetensi guru dalam pembelajaran menjadi bagian terpenting dalam mendukung terciptanya proses pembelajaran secara efektif.

Moodle (Modular Object Oriented Dynamic Learning Environtment) merupakan salah satu jenis e-learning berbasis teknologi informasi yang menggunakan open source dalam bentuk website yang digunakan dalam proses pembelajaran untuk memperoleh informasi yang sangat luas. Melalui moodle materi pembelajaran dapat diakses kapan saja dan dari mana saja. Penggunaan moodle dalam pembelajaran sangat membantu guru untuk membuat media pembelajaran yang interaktif. Media pembelajaran yang interaktif dapat meningkatkan minat belajar siswa terhadap mata pelajaran yang diberikan oleh guru.

Berdasarkan hasil observasi dan wawancara kepada Ibu Alfia Susan sebagai wakil kepala sekolah bidang kurikulum di SMAN 100 Jakarta diperoleh informasi bahwa masih rendahnya kinerja guru dalam menyusun soal dapat dilihat dari penggunaan tes yang sudah ada kemudian disesuaikan dengan materi ajar. Sebagian besar guru dalam menyusun soal belum sesuai dengan kaidah penulisan soal, misalnya pemilihan materi yang kurang tepat, konstruksi soal belum dirumuskan secara jelas dan penggunaan bahasa yang kurang tepat. Dalam menyusun soal, guru sebaiknya mengikuti kaidah penulisan soal yang sudah ditetapkan oleh Kemendikbud.

Dalam melakukan penyusunan soal untuk peserta didik, guru masih menggunakan cara konvensional dimana belum adanya media berbasis teknologi informasi yang mendukung dalam penyusunan soal yang telah dibuat guru. Kurangnya pengetahuan guru akan teknologi informasi media pembelajaran berbasis moodle dikarenakan belum adanya pelatihan untuk guru dalam menggunakan moodle dalam penyusunan soal. Pelatihan untuk guru sangat penting dalam meningkatkan kinerja guru 
sendiri dalam menyusun soal berbasis teknologi dan penggunaan teknologi sebagai media pembelajaran. Maka dari itu, perlu dilakukan pelatihan untuk guru di SMAN 100 Jakarta.

\subsection{Pembatasan Masalah}

Untuk lebih memfokuskan masalah yang akan diteliti, maka penelitian akan dibatasi pada:

1. Palatihan difokuskan untuk semua guru dalam menyusun soal menggunakan moodle di SMAN 100 Jakarta.

2. Pelatihan difokuskan untuk membahas dua kompetensi yaitu kompetensi pedagogik dan kompetensi profesional.

\subsection{Rumusan Masalah}

Berdasarkan latar belakang, identifikasi dan pembatasan masalah tersebut, maka permasalahan pada penelitian ini adalah "Adakah pengaruh pelatihan penyusunan soal menggunakan moodle terhadap kinerja guru dalam menyusun soal di SMAN 100 Jakarta?".

\section{Kajian Teoritik}

2.1 Deskripsi Konseptual

\subsubsection{Kinerja Guru}

\subsubsection{Definisi Guru}

Guru adalah salah satu komponen manusiawi dalam proses belajar mengajar, yang ikut berperan dalam usaha pembentukan sumber daya manusia yang potensial di bidang pembangunan (Sardiman, 2014:125). Menurut Supardi (2016:8) pengertian guru secara formal tertulis dalam UndangUndang Nomor 14 Tahun 2005 diartikan sebagai pendidik profesional dengan tugas utama mendidik, mengajar, membimbing, mengarahkan, melatih, menilai dan mengevaluasi siswa pada pendidikan anak usia dini jalur pendidikan formal, pendidikan dasar, dan pendidikan menengah.

Menurut Djamarah (2015:280) guru adalah seseorang yang memberikan ilmu pengetahuan kepada anak didik atau tenaga profesional yang dapat menjadikan murid-muridnya untuk merencanakan, menganalisis dan menyimpulkan masalah yang dihadapi. Berdasarkan pengertian guru dari beberapa ahli dapat disimpulkan bahwa guru adalah seorang tenaga profesional yang berpengalaman dibidang profesinya dengan tugas utama mendidik, mengajar, membimbing, mengarahkan, melatih, menilai dan mengevaluasi siswa bertujuan membuat siswa menjadi orang yang cerdas.

\subsubsection{Definisi Kinerja Guru}

Menurut Mangkunegara (dalam Jasmani, 2013:155) kinerja adalah hasil kerja secara kualitas dan kuantitas yang dicapai oleh seorang pegawai dalam melaksanakan tugasnya sesuai dengan tanggung jawab yang diberikan kepadanya. Menurut Prawiro Suntoro (dalam Tika, 2014:121) kinerja merupakan hasil kerja yang dapat dicapai oleh seseorang atau sekelompok orang dalam suatu organisasi demi mencapai tujuan organisasi dalam jangka waktu tertentu.

Berdasarkan uraian yang ada dapat disimpulkan kinerja guru merupakan hasil kerja nyata baik dalam hal kualitas maupun kuantitas yang dilakukan oleh guru untuk memberikan suatu hasil dan tujuan berdasarkan tanggung jawab yang telah diberikan.

\subsubsection{Penilaian Kinerja Guru}

Penilaian kinerja seorang guru dilakukan untuk mengetahui kinerja yang sudah dicapai oleh seorang guru. Penilaian ini sangat penting untuk guru untuk mengetahui tinggi rendahnya kinerja yang telah dicapai. Pada dasarnya penilaian dapat dilihat dari kompetensi seorang guru. Menurut Undang-undang no.14 tahun 2005 dalam Supardi (2016:69) meliputi empat kompetensi yaitu:(1) kompetensi pedagogik; (2) kompetensi kepribadian; (3) kompetensi sosial; (4) kompetensi profesional.

Selanjutnya kompetensi guru dijelaskan dalam Peraturan Menteri Pendidikan Nasional Republik Indonesia (Permendiknas) no. 16 tahun 2007 tentang Standar Kompetensi guru

\subsubsection{Pelatihan Penyusunan Soal \\ 2.1.2.1 Dedinisi Pelatihan}

Pelatihan merupakan serangkaian aktivitas individu dalam meningkatkan keahlian dan pengetahuan secara sistematis sehingga mampu memiliki kinerja yang professional dibidangnya (Widodo, 2015:82). Menurut Caple dalam Donni (2014:173) pelatihan merupakan upaya sistematis dan terencana untuk mengubah atau mengembangkan pengetahuan, keterampilan dan sikap melalui pengalaman belajar dalam rangka meningkatkan efektivitas kinerja.

\subsubsection{Definisi Pelatihan Guru}

Program pelatihan merupakan sebuah program untuk penguasaan berbagai keterampilan dan teknik pelaksanaan kerja untuk kebutuhan sedangkan pengembangan bertujuan untuk mempersiapkan karyawan memangku jabatan di masa yang akan datang. Untuk meningkatkan profesionalisme guru, perlu adanya pelatihan dan pendidikan. Pelatihan yang dilakukan untuk guru akan disesuaikan dengan kebutuhan guru, yaitu pelatihan yang mengarah kepada peningkatan kompetensi guru (Saondi dan Suherman, 2010:79).

Menurut Barnawi dan Arifin (2014;80) pelatihan guru dapat digunakan untuk menangani randahnya kemampuan guru. Program pelatihan akan diberikan berdasarkan dengan kebutuhan guru di sekolah sehingga jenis pelatihan yang akan digunakan harus diprogramkan terlebih dahulu dan sesuai dengan kemampuan guru yang masih rendah. Pelatihan guru akan lebih efisien jika dirancang sesuai dengan kebutuhan, waktu pelaksanaan, dan metode yang akan digunakan. 


\subsubsection{Pelatihan Penyususunan Soal}

Menurut Zainal Arifin (2016: 188) tes merupakan suatu teknik yang digunakan dalam rangka melaksanakan kegiatan pengukuran yang di dalamnya terdapat berbagai pertanyaan, atau serangkaian tugas yang harus dikerjakan atau dijawab oleh peserta didik untuk mengukur aspek perilaku peserta didik. Menurut Zainal Arifin (2016: 125-150) tes dibedakan atas beberapa bentuk yaitu:(1) bentuk uraian; (2) bentuk objektif; (3) tes lisan; (4) tes perbuatan.

Menurut Arikunto (2013:72) sebuah tes dapat dikatakan baik sebagai alat pengukur harus memenuhi persyaratan tes yaitu memiliki validitas, reliailitas, objektivitas, praktibilitas dan ekonomis. Berdasarkan uraian yang ada dapat disimpulkan bahwa penyusunan soal dilakukan oleh guru untuk menghasilkan bahan ulangan atau ujian yang baik sesuai dengan tujuan yang diinginkan.

\section{Metodologi Penelitian} 3.1 Tujuan Penelitian

Tujuan dari penelitian ini adalah untuk melihat adanya pengaruh positif antara pelatihan dengan kinerja guru pada pelatihan penyusunan soal untuk guru di SMAN 100 Jakarta.

\subsection{Tempat dan Waktu Penelitian}

Penelitian dilakukan di SMAN 100 Jakarta, yang berlokasi di Jalan Persatuan 2, Cipinang Besar Selatan, Jatinegara, Jakarta Timur 13420. Penelitian dilakukan khusus untuk melakukan pelatihan terhadap guru disekolah sebanyak 37 orang. Penelitian dilakukan sebanyak lima kali

\subsection{Metode Penelitian}

Metode penelitian yang digunakan menggunakan metode survey (Field Studies) dengan menggunakan pendekatan korelasional. Metode survey digunakan untuk mendapatkan data penelitian dari tempat tertentu yang alamiah dan tanpa mendapatkan perlakuan khusus dalam pengumpulan data (Sugiyono, 2016:6).

\subsection{Teknik Pengumpulan Data}

Untuk pengumpulan data yang berhubungan dengan permasalahan yang akan dikaji, maka pengumpulan data yang dilakukan dengan teknik sebagai berikut: 1) Observasi, 2) Wawancara, 3) Kuesioner (Angket) dan 4) Dokumentasi.

\subsubsection{Instrumen Variabel Kinerja Guru \\ 3.4.1.1 Definisi Konseptual}

Secara definisi konseptual kinerja guru adalah ukuran tingkat kemampuan guru setelah mengalami suatu proses dalam jangka waktu tertentu. Untuk mengukur kinerja guru dapat dilakukan berdasarkan empat kompetensi yang dimiliki yaitu kompetensi pedagogik, kompetensi kepribadian, kompetensi sosal dan kompetensi professional.

\subsubsection{Definisi Operasional}

Terdapat faktor-faktor yang mempengaruhi kinerja guru yaitu meliputi empat kompetensi, tetapi pada penelitian ini hanya akan membahas dua kompetensi yaitu kompetensi pedagogik dan kompetensi professional. Adapun indikator dari kompetensi pedagogik meliputi menguasai teori belajar dan prinsip pembelajaran, mengembangkan kurikulum, penyelenggaraan pembelajaran mendidik, memanfaatkan teknologi informasi dan komunikasi untuk kepentingan pembelajaran, melakukan evaluasi dan penilaian dari hasil belajar. Indikator yang dilihat dari kompetensi professional antara lain mengusai materi, struktur, konsep, dan pola pikir keilmuan yang mendukung dalam proses pembelajaran, menguasai standar kompetensi dan kompetensi dasar mata pelajaran yang diampu, memanfaatkan teknologi dan komunikasi untuk mengembangkan diri.

\subsubsection{Pengujian Validitas dan Perhitungan Realiabilitas}

1. Pengujian Validitas Instrumen

Analisis uji validitas soal pilihan ganda Mata Pelajaran Komposisi Foto Digital Kelas XI Multimedia akan dibuat persentase kelayakan untuk setiap pertanyaan yang kemudian akan dideskripsikan. Pemberian skor pada jawaban setiap butir diolah dengan menggunakan rumus Content Validity Ratio (CVR) sebagai berikut:

$$
\mathrm{CVR}=\{\mathrm{Ne}-(\mathrm{N} / 2)\} /(\mathrm{N} / 2)
$$

Keterangan:

$\mathrm{Ne}$ : Jumlah validator yang menyatakan "cocok"

\section{$\mathrm{N}$ : Total responden}

Setelah hasil dari CVR yang telah didapat, ditentukan cocok dan ketidak cocokan antara soal dan indikator dengan ketentuan jika hasil dari uji CVR > $0 \rightarrow$ butir soal cocok digunakan sebaliknya jika hasil dari uji CVR $\leq 0 \rightarrow$ butir soal tidak cocok digunakan

\section{Pengujian Validitas Soal}

Setelah melakukan pengujian instrumen dilakukan pengujian validitas soal. Validitas soal dilakukan untuk mengetahui kecermatan dan ketepetan suatu tes sesuai dengan fungsi pengukurannya. Validasi instrumen soal dihitung dengan rumus korelasi Point Biserial untuk melihat hubungan antara dua variabel. Pengujian validitas menggunakan rumus Korelasi Point Biserial oleh Arikunto (2010: 93)

$$
r_{p b i}=\frac{M_{p}-M_{t}}{S D_{t}} \sqrt{\frac{p}{q}}
$$


Keterangan:

$\mathrm{r}_{\mathrm{pbi}}=$ koefisien Korelasi Biserial

$\mathrm{M}_{\mathrm{p}}=$ rata-rata skor dari subjek yang menjawab

benar bagi item yang dicari validitasnya

$\mathrm{M}_{\mathrm{t}}=$ rata-rata skor yang dicapai oleh peserta tes yang menjawab salah

$\mathrm{SD}_{\mathrm{t}}=$ standar deviasi dari skor total proporsi

$\mathrm{p}=$ proporsi peserta tes yang menjawab

benar $\left[\mathrm{p}=\frac{\text { banyak guru yang benar }}{\text { jumlah seluruh guru }}\right]$

$\mathrm{q}=$ proporsi peserta tes yang menjawab salah

$(q=1-p)$

dimana:

$$
S D_{t}=\sqrt{\frac{\sum X_{i}^{2}}{n}-\frac{\left(\sum X_{i}\right)^{2}}{n}}
$$

Keterangan:

$X_{i}=$ nilai data ke- $i$

$n=$ jumlah responden

Nilai $r_{p b i}$ yang didapat kemudian dikonfirmasikan dengan $r_{\text {tabel }} \geq 0,3061$ dengan ketentuan jika suatu butir soal dengan $r_{p b i} \geq 0,3061$ maka soal tersebut valid.

Sebaliknya jika suatu butir soal dengan $r_{p b i}<0,3061$ maka soal tersebut tidak valid.

Selanjutnya, butir-butir pernyataan yang dinyatakan valid dihitung reliabilitasnya dengan rumus Kuder Richardson. Rumus KR-20 menurut Arikunto (2010: 223) yaitu:

$$
r_{11}=\frac{n}{(n-1)}\left\{\frac{s^{2}-\sum p q}{s^{2}}\right\}
$$

Keterangan:

$r_{11}=$ Reliabilitas instrumen

$n=$ Banyaknya butir pernyataan (banyak soal)

$s^{2}=$ varians total

$\sum p q \quad=$ jumlah skor benar dan salah

Dimana:

$$
S^{2}=\frac{\sum X^{2}-\frac{\left(\sum X\right)^{2}}{n}}{n}
$$

Hasil dari perhitungan $r_{11}$ untuk menginterpretasikan koefisien $\left(r_{11}\right)$ menggunakan table kategori sebagai patokan untuk mengetahui tingkat reliabilitas instrumen dapat dilihat pada Tabel 3.1.

Tabel 3.1 Tabel Interpretasi Nilai $r$

\begin{tabular}{|c|c|}
\hline $\begin{array}{c}\text { Besarnya } \\
\text { Nilai } \mathbf{r}\end{array}$ & Interpretasi \\
\hline $0,8-1$ & Sangat Tinggi \\
\hline $0,6-0,8$ & Tinggi \\
\hline $0,4-0,6$ & Cukup \\
\hline $0,2-0,6$ & Rendah \\
\hline $0-0,2$ & Sangat Rendah \\
\hline
\end{tabular}

Instrumen dikatakan reliabel jika $r_{\text {hitung }} \geq$ $r_{\text {tabel }}$ dan sebaliknya jika $r_{\text {hitung }}<r_{\text {tabel }}$ maka instrumen dikatakan tidak reliable.

\subsection{Teknik Analisis Data}

Berdasarkan permasalahan dan tujuan penelitian yang diajukan mengenai pengaruh pelatihan penyusunan soal terhadap kinerja guru dalam menyusun soal di SMAN 100 Jakarta, maka teknik analisis data yang akan digunakan dalam penelitian ini adalah:

\subsubsection{Uji Persyaratan Analisis Data \\ 3.5.1.1 Uji Normalitas Data}

Uji normalitas data dilakukan untuk mengetahui kenormalan suatu data tentang pelatihan (variabel $\mathrm{x}$ ) dan kinerja guru (variabel y) yang ditelah dikumpulkan datanya. Untuk mengetahui kenormalan suatu data maka menggunakan rumus Liliefors oleh Sudjana (2013: 466) dengan rumus:

Keterangan :

$$
\mathrm{L}_{\text {hitung }}=|\mathrm{F}(\mathrm{zi})-\mathrm{S}(\mathrm{zi})|
$$

$\mathrm{L}_{\text {hitung }}=$ Hasil Lilifors

$\mathrm{F}(\mathrm{zi})=$ Probabilitas komulatif normal

$\mathrm{S}(\mathrm{zi})=$ Probabilitas komulatif empiris

Kriteria yang dilakukan jika $\mathrm{L}_{\text {hitung }}>\mathrm{L}_{\text {tabel }}$ maka tolak $\mathrm{H}_{0}$ (Data tidak terdistibusi normal, apabila $\mathrm{L}_{\text {hitung }}<\mathrm{L}_{\text {tabel }}$ maka terima $\mathrm{H}_{0}$ (Data terdistribusi normal). Pada taraf signifikansi yang di terima yaitu $\alpha=0,05$.

\subsubsection{Korelasi Sederhana}

Untuk mendapatkan hubungan antara variabel bebas dengan variabel terikat peneliti menggunakan rumus korelasi sederhana (Sugiyono, 2016:183), yaitu:

$$
r_{x y}=\frac{\mathrm{N} \Sigma \mathrm{XY}-(\Sigma \mathrm{X})(\Sigma \mathrm{Y})}{\sqrt{\left\{\mathrm{N} \Sigma \mathrm{X}^{2}-(\Sigma \mathrm{X})^{2}\right\}\left\{\mathrm{N} \Sigma \mathrm{Y}^{2}-(\Sigma \mathrm{Y})^{2}\right\}}}
$$

Keterangan:

$r_{x y}:$ koefisien korelasi

$\sum x$ : jumlah skor distribusi $\mathrm{X}$

$\sum y$ : jumlah skor distribusi $\mathrm{Y}$

Hasil dari perhitungan $r_{x y}$ untuk melihat adanya korelasi yang terdapat antara pelatihan penyusunan soal dengan kinerja guru. Untuk melihat korelasi tersebut menggunakan table kategori sebagai patokan untuk mengetahui tingkat reliabilitas instrumen dapat dilihat pada Tabel 3.2.

Tabel 3.2 Pedoman Untuk Melihat Interpretasi Koefisien Korelasi

\begin{tabular}{|c|c|}
\hline Besarnya Nilai r & Interpretasi \\
\hline $0,80-1$ & Sangat Kuat \\
\hline $0,60-0,799$ & Kuat \\
\hline $0,40-0,599$ & Sedang \\
\hline $0,20-0,399$ & Rendah \\
\hline $0-0,199$ & Sangat Rendah \\
\hline
\end{tabular}

\subsection{Hipotesis Statistik}

Perumusan hipotesis statistika dalam penelitian ini adalah sebagai berikut:

$\mathrm{H}_{\mathrm{o}} \quad: \quad \rho_{Y}=0$ (artinya tidak terdapat hubungan yang positif dan signifikan antara pelatihan penyusunan soal dengan kinerja guru dalam menyusun soal tes) $\mathrm{H}_{1}: \rho_{Y} \neq 0$ (artinya terdapat hubungan yang positif dan signifikan antara pelatihan penyusunan soal dengan kinerja guru dalam menyusun soal tes). 


\section{Penelitian dan Pembahasan}

\subsection{Deskripsi Data}

Penelitian ini bertujuan untuk mengetahui apakah ada hubungan positif dan signifikan antara pelatihan penyusunan soal $(\mathrm{X})$ dengan kinerja guru dalam menyusun soal (Y) di SMA Negeri 100 Jakarta. Hasil dari jawaban kuesioner yang telah dikumpulkan dalam penelitian ini, kemudian dianalisis. Pada penelitian ini jumlah guru yang mengikuti pelatihan penyusunan soal sebanyak 37 guru. Data dari hasil penelitian dapat dideskripsikan untuk memperoleh gambaran untuk nilai hasil dari pelatihan penyusunan soal yang dilakukan guru terhadap kinerja guru di sekolah.

\subsection{Pengujian Persyaratan Analasis Data 4.2.1 Uji Validitas}

\subsubsection{Uji Validitas Instrumen}

Uji validasi instrumen dilakukan untuk menelaah instrumen yang telah disusun dengan tujuan untuk menghasilkan instrumen yang berkualitas untuk kegiatan pengujian. Analisis validasi instrumen ahli menggunakan skala Guttman untuk menguji kelayakan pada setiap pertanyaan yang kemudian akan dideskripsikan. Instrumen terdiri dari 26 instrumen kinerja guru dan 20 instrumen pelatihan penyusunan soal. Pemberian skor pada jawaban setiap butir diolah dengan menggunakan Content Validity Ratio (CVR). Setelah semua item mendapat skor, kemudian skor tersebut diolah dengan rumus $C V R$. Hasil skor relevansi instrumen butir soal yang dilakukan oleh 3 validator dapat dilihat pada Lampiran 4.

Setelah validator menilai instrumen dari setiap aspek, indikator, dan pertanyaan, maka langkah selanjutnya adalah membuat tabulasi dengan mengisi skor yang diberikan 3 ahli validasi

\subsubsection{Uji Validitas Soal}

Peneliti melakukan uji validasi instrumen soal dengan responden 37 guru. Instrumen ini berbentuk pertanyaan berbentuk soal pilihan ganda dengan 2 macam pilihan ganda dengan jumlah 46 soal yang terdiri dari 26 soal untuk pertanyaan tentang kinerja guru dan 20 soal untuk pertanyaan tentang pelatihan penyusunan soal. Rumus yang digunakan untuk pengujian validitas adalah Korelasi Point Biserial. Berdasarkan hasil uji validitas, untuk uji validitas kinerja guru, dari 26 butir soal, terdapat 2 soal yang tidak valid, yaitu: soal 5 dan soal 7. Sehingga didapat 24 soal yang digunakan untuk penelitian. Sedangkan untuk validitas instrumen pelatihan penyusunan soal, dari 20 butir soal yang diuji, terdapat 1 soal yang tidak valid, yaitu soal 2. Sehingga didapat 19 soal yang digunakan untuk penelitian.

\subsubsection{Uji Reliabilitas}

Setelah melakukan analisis uji validasi, kemudian peneliti menghitung realiabilitas terhadap 46 soal menggunakan rumus KR-20, diperoleh bahwa instrumen soal pertanyaan tentang kinerja guru dalam menyusun soal tes memiliki indek reliabilitas sebesar
0,803 dan instrumen soal pertanyaan tentang pelatihan penyusunan soal memiliki indek reliabilitas sebesar 0,813. Angka tersebut menyatakan bahwa kedua instrumen tersebut memiliki konsistensi yang tinggi, artinya soal yang dibuat reliabel.

\subsubsection{Uji Normalitas Data}

Uji normalitas data digunakan untuk melihat apakah data yang diteliti berdistribusi normal atau tidak. Data akan dikatakan baik jika data yang digunakan berdistribusi dengan normal. Pada penelitian ini, uji normalitas yang dilakukan menggunakan uji Liliefors dengan kriteria:

$\mathrm{H}_{0}$ : Data berdistribusi normal

$\mathrm{H}_{1}$ : Data tidak berdistribusi normal

1. Jika $\mathrm{L}_{\text {hitung }}>\mathrm{L}_{\text {tabel }}$ maka tolak $\mathrm{H}_{0}$ (Data tidak terdistibusi normal)

2. Jika $\mathrm{L}_{\text {hitung }}<\mathrm{L}_{\text {tabel }}$ maka terima $\mathrm{H}_{0}$ (Data terdistribusi normal)

Setelah melakukan perhitungan uji normalitas data diperoleh hasil untuk data instrumen kinerja guru dengan $\mathrm{L}_{\text {hitung }} 0,138$ dan diperoleh hasil untuk data instrumen pelatihan penyusnan soal $\mathrm{L}_{\text {hitung }} 0,141$ dengan $\mathrm{L}_{\text {tabel }}$ 0,146. Hasil dari $\mathrm{L}_{\text {hitung }}$ kedua data tersebut lebih kecil dari $\mathrm{L}_{\text {tabel }}$, yang artinya bahwa data dari kedua instrumen berdistribusi normal.

\subsection{Pengujian Hipotesis}

Setelah terbukti semua data penelitian berdistribusi normal, selanjutnya dilakukan pengujian hipotesis. Hipotesis dalam penelitian ini adalah terdapat hubungan positif antara pelatihan penyusunan soal menggunakan moodle dengan kinerja guru dalam menyusun soal tes di SMAN 100 Jakarta. Hipotesis tersebut merupakan bentuk assosiatif (hubungan) yang memiliki 1 variabel bebas (X) dan satu variabel terikat (Y). Untuk menguji hipotesis tersebut peneliti menggunakan rumus korelasi sederhana (r). Dari hasil perhitungan korelasi diperoleh hasil 0,735 yang artinya bahwa korelasi antara variabelx dengan variabel y kuat.

\subsection{Pembahasan Hasil Penelitian}

Berdasarkan hasil pengujian data yang telah dilakukan dapat disimpulkan bahwa pengujian hipotesis memperoleh keputusan bahwa terdapat hubungan positif dan signifikan antara Pelatihan Penyusunan Soal dengan Kinerja Guru dalam Menyusun Soal Tes di SMAN 100 Jakarta. Tahap awal penelitian adalah observasi yang dilakukan pada saat kegiatan pembelajaran berlangsung, dengan tujuan untuk mengetahui kinerja guru dalam proses pembelajaran berlangsung. Kemudian, melakukan wawancara dengan guru SMAN 100 Jakarta. Setelah peneliti mendapatkan data awal melalui observasi dan wawancara, maka tahap selanjutnya adalah membuat instrumen kinerja guru dan instrumen pelatihan penyusunan soal yang digunakan sebagai data hasil penelitian.

Hasil uji validitas kinerja guru, dari 26 butir soal, terdapat 2 soal yang tidak valid. Sehingga, didapat 24 soal yang digunakan untuk penelitian. Sedangkan untuk uji validitas instrumen pelatihan 
penyusunan soal, dari 20 butir soal yang diuji, terdapat 1 soal yang tidak valid. Sehingga, didapat 19 soal yang digunakan untuk penelitian. Hasil uji reliabilitas yang dilakukan untuk instrumen

soal pertanyaan tentang kinerja guru dalam menyusun soal tes memiliki indek reliabilitas $=0,803$ dan instrumen soal pertanyaan tentang pelatihan penyusunan soal memiliki indek reliabilitas $=0,813$. Angka tersebut menyatakan bahwa kedua instrumen tersebut memiliki konsistensi yang tinggi, artinya soal yang dibuat reliabel.

Berdasarkan data yang telah diperoleh, peneliti menguji terlebih dahulu data tersebut dengan tujuan mengetahui karakteristik data menggunakan uji normalitas dan pengujian hipotesis. Dari perhitungan uji normalitas data, diperoleh hasil untuk data instrumen kinerja guru dengan $\mathrm{L}_{\text {hitung }}=0,138$ dan data instrumen pelatihan penyusnan soal $\mathrm{L}_{\text {hitung }}=0,141$ dengan $\mathrm{L}_{\text {tabel }}=0,146$. Artinya, data dari kedua instrumen berdistribusi normal. Sedangkan untuk hasil pengujian hipotesis memperoleh nilai 0,735 . Artinya, korelasi antara variabel $\mathrm{x}$ dan variabel $\mathrm{y}$ kuat. Data ini menunjukkan bahwa terdapat hubungan yang positif antara pelatihan penyusunan soal menggunakan moodle dengan kinerja guru dalam menyusun soal tes di SMAN 100 Jakarta.

\section{Kesimpulan dan Saran}

\subsection{Kesimpulan}

Berdasarkan hasil penelitian yang telah dilakukan maka dapat disimpulkan bahwa terdapat pengaruh antara Pelatihan Penyusunan Soal menggunakan moodle dengan Kinerja Guru dalam Menyusun Soal Tes. Semakin tinggi hasil pelatihan penyusunan soal yang dilakukan oleh guru maka hasil dari kinerja guru juga akan semakin tinggi. Sebaliknya jika hasil dari pelatihan penyusunan soal menurun maka kinerja guru juga akan menurun. Hal tersebut dapat menjadi pertimbangan karena akan mempengaruhi proses pembelajaran dikelas.

\subsection{Implikasi}

Berdasarkan kesimpulan di atas bahwa terdapat hubungan positif antara Pelatihan Penyusunan Soal Menggunakan Moodle dengan Kinerja Guru dalam Menyusun Butir Soal Test, maka implikasi dari penelitian ini adalah sebagai berikut:

1. Pengetahuan guru akan penyusunan soal yang baik dan benar sesuai dengan kaidah-kaidah pembuatan dan penyusunan soal semakin baik dan perlu untuk ditingkatkan agar mendapatkan hasil yang lebih baik.

2. Pelatihan penyusunan soal untuk guru sangat diperlukan untuk meningkatkan kinerja guru di SMAN 100 Jakarta karena akan berpengaruh terhadap kegiatan belajar mengajar disekolah.

\subsection{Saran}

Berdasarkan hasil penelitian dan kesimpulan di atas, maka penulis menuliskan saran sebagai berikut:

1 Pelatihan untuk guru dilakukan secara berkala di sekolah dengan tujuan untuk terus meningkatkan kinerja guru menjadi lebih baik lagi.

2 Meningkatkan pengetahuan guru akan pentingnya membuat dan menyusun soal sesuai dengan kaidah-kaidah pembuatan soal.

3 Pengetahuan akan ilmu teknologi informasi ditingkatkan untuk mengembangkan potensi yang dimiliki oleh guru.

\section{Daftar Pustaka:}

Arifin, Barnawi dan M. (2014). Manajemen Sarana dan Prasarana Sekolah. Yogyakarta: Ar-ruzz Media.

Arifin, Zainal. (2016). Evaluasi Pembelajaran (Prinsip, Teknik, dan Prosedur), Cetakan Kedelapan. Jakarta: Rosda Karya

Eko, Widodo Suparno. (2015). Manajemen Pengembangan Sumber Daya Manusia. Yogyakarta: PUSTAKA PELAJAR.

Djamarah, Syaiful Bahri. (2015). Psikologi Belajar. Jakarta : Rineka Cipta.

Jasmani \& Mustofa, Syaiful. (2013). Supervisi Pendidikan: Trobosan Baru dalam Kinerja Peningkatan Kerja Pengawas Sekolah dan Guru. Yogyakarta: ArRuzz Media.

Priansa, Donni Junni (2014), Perencanaan \& Pengembangan SDM. Penerbit Bandung: Alfabeta

Saondi, Ondi dan Aris Suherman. (2010). Etika Profesi Keguruan. Bandung: PT Refika Aditama.

Sardiman. (2014). Interaksi dan Motivasi Belajar Mengajar. Depok: PT. Rajagrafindo Persada. Sugiyono.(2016). Metode Penelitian Kuantitatif, Kualitatif dan R\&D. Bandung. Alfabeta

Supardi. (2016). Kinerja Guru. Jakarta: Raja Grafindo Persada.

Tika, Pabundu. (2014). Budaya Organisasi dan Peningkatan Kinerja Perusahaan. Jakarta: Bumi Aksara 